\title{
PREVALENSI DAN FAKTOR-FAKTOR YANG BERKAITAN DENGAN PELAYANAN SWAMEDIKASI DI APOTEK
}

\section{(PREVALENCE AND FACTORS RELATED TO SELF-PRESCRIPTION SERVICES IN PHARMACIES)}

\author{
NI MADE OKA DWICANDRA*•, NI PUTU WINTARIANI* \\ "Prodi Farmasi Klinis, Institut Ilmu Kesehatan Medika Persada Bali,
}

\begin{abstract}
Abstrak: Tingginya kejadian swamedikasi dan banyaknya penggunaan obat yang tidak tepat dalam swamedikasi perlu menjadi perhatian. Penelitian ini bertujuan menentukan prevalensi layanan swamedikasi di Apotek, karakteristik pasien yang melakukan layanan swamedikasi, dan faktor-faktor yang berkaitan dengan layanan swamedikasi di Apotek. Studi dilakukan pada 230 pasien yang melakukan pelayanan kefarmasian (layanan resep maupun swamedikasi di wilayah Denpasar dan Badung. Rancangan penelitian yang digunakan adalah cross sectional. Hasil penelitian menunjukkan sebanyak $60,4 \%$ pasien yang berkunjung ke Apotek menggunakan layanan swamedikasi. Pasien yang mendapatkan layanan swamedikasi didominasi oleh pasien perempuan, pasien yang tidak hamil, tidak merokok, pasien yang menikah, tingkat pendidikan SMA, latar belakang pendidikan non kesehatan, tanpa penyakit kronis, dan tidak mengkonsumsi alkohol. Sebanyak lebih dari $65 \%$ pasien yang mendapatkan layanan swamedikasi memiliki tingkat keluhan penyakit yang ringan. Rata-rata umur pasien yang mendapatkan layanan swamedikasi adalah 35,06 $\pm 15,35$ tahun. Faktor-faktor yang berhubungan dengan kejadian swamedikasi di Apotek wilayah Denpasar dan Badung adalah status merokok, tingkat pendidikan pasien, latar belakang pendidikan pasien, jarak tempat tinggal, tingkat keluhan, dan harga obat $(\mathrm{p}<0,05)$.
\end{abstract}

Kata kunci : faktor risiko, prevalensi, resep, swamedikasi.

\begin{abstract}
The high incidence of self-prescription and the number of improper use of drugs in self-prescription need to be a concern. This research aimed to determine the prevalence of self-prescription service at the pharmacy, the characteristics of the patients who did the self-prescription service and factors related to the self-prescription service at the pharmacy. The study was conducted on 230 patients who perform pharmaceutical services (prescription as well as self-prescription) in Denpasar and Badung. The research design used was cross sectional. The results showed as many as $60.4 \%$ of patients visiting Pharmacies using the self-prescription service. Patients who get the self-prescription service is dominated by female patients, patients who did not get pregnant, don't smoke, patients who are married, high school level of education, the non health educational background, without a chronic disease, and do not consume alcohol. More than 65\% of patients who get the self-prescription service have a mild level of illness. The average age of patients who get the self-prescription service is $35.06 \pm 15.35$ years. Factors related to the incidence of self-prescription in Pharmacy of Badung and Denpasar is the smoking status, level of education of the patient, the patient's educational background, the distance of the place of residence, level of complaints, and drug prices $(\mathrm{p}<0.05)$.
\end{abstract}

Keyword: prescription, prevalence, risk factor, self-medication.

\section{PENDAHULUAN}

Dalam beberapa dekade terakhir, peran apoteker telah berubah, yaitu tidak hanya sebagai drug supplier, namun bertindak sebagai bagian dari tim multidisiplin yang terlibat dalam pelayanan kesehatan, khususnya pelayanan kefarmasian (Petty, 2003). Pelayanan kefarmasian semakin dirasa penting dengan adanya tantangan pada pelayanan swamedikasi (Galato et al., 2009). Berbagai studi menunjukkan tingginya tingkat swamedikasi di mayarakat. (Kasilo, Nacho and Mutangadura, 1991; Shankar and Partha P, 2002; Figueroas, Cacmaso and Guestal, 2011).

Organisasi WHO mempromosikan praktik swamedikasi untuk mengatasi gejala penyakit

\footnotetext{
• Author correspondence. e-mail: okadwicandra@gmail.com
} 
dengan cepat dan efektif tanpa konsultasi medis dan mengurangi beban pada layanan perawatan kesehatan, yang sering kekurangan tenaga dan tidak dapat diakses di daerah pedesaan dan terpencil (WHO, 2000). Dalam praktek swamedikasi, penggunaan obat-obatan berpotensi untuk memberikan manfaat sekaligus menimbulkan bahaya.

Berbagai literatur menunjukkan adanya manfaat dari kegiatan swamedikasi. World Health Organization (WHO) telah menyatakan bahwa swamedikasi yang bertanggung jawab dapat membantu mencegah dan mengobati penyakit yang tidak memerlukan konsultasi medis dan memberikan alternatif yang lebih murah untuk mengobati common ill-nesses (Clavinjo, 1995; WHO, 2000; AESGP, 2004)

Namun, selain banyaknya manfaat dalam swamedikasi, ketersediaan obat-obatan dengan mudah tanpa resep dokter menjadi faktor utama yang bertanggung jawab atas penggunaan obatobatan yang tidak rasional dalam swamedikasi (Tenaw and Tsige, 2004; Pagane et al., 2007).

Obat OTC (over the counter) yang dimaksudkan untuk swamedikasi dan efektifitas dan keamanannya sudah terbukti, apabila penggunaannya kurang tepat dapat berdampak serius, terutama pada usia ekstrim (anak-anak dan geriatri) dan kondisi fisiologis khusus seperti kehamilan dan menyusui (Choonar and Gill, 1996; Murray and Callaran, 2003). Beberapa risiko lainnya terkait dengan swamedikasi adalah adanya misdiagnosis, penggunaan dosis obat yang berlebih, durasi penggunaan obat yang terlalu lama (Tenaw and Tsige, 2004).

Terlepas dari manfaat dan bahaya yang ditimbulkan oleh swamedikasi, kejadian swamedikasi ini masih terbilang tinggi. Berbagai faktor mempengaruhi keputusan pasien dalam memilih swamedikasi sebagai solusi untuk masalah kesehatannya. Tingkat pendidikan dan status profesional yang tinggi, penyakit yang dianggap ringan, pengalaman sebelumnya dalam mengobati penyakit serupa, pertimbangan ekonomi dan kurangnya ketersediaan tenaga kesehatan, pengalaman akan pengobatan ulang penyakit serupa (Hughes, McElnay and Fleming, 2001; Martins et al., 2002; Shankar, Partha and Shenoy, 2002; James et al., 2006; Sawalha, 2008; Abay and Amelo, 2010; Ocan et al., 2014).
Tingginya tingkat swamedikasi dan
adanya banyak faktor yang mendorong swamedikasi tentu perlu menjadi perhatian bagi seorang apoteker. Hal yang menegaskan tanggung jawab seorang apoteker dalam pelayanan swamedikasi adalah studi yang dilakukan oleh Loyola menemukan hubungan yang signifikan antara konsultasi apoteker dan penggunaan nonprescribed drugs di Bambuí, Minas Gerais (Loyola Filho et al., 2002). Apoteker berhasil mengatasi serangkaian gangguan kesehatan ringan, yang mengakibatkan hanya sejumlah kecil pasien harus kembali ke dokter (Whittington et al., 2001).

Agar dapat meningkatkan pelayanan kesehatan masyarakat dan memaksimalkan manfaat swamedikasi, serta meminimalkan potensi bahaya yang ditimbulkan oleh swamedikasi, perlu dilakukan studi mengenai profil atau karakteristik pasien yang mendapatkan pelayanan swamedikasi. Dengan mengetahui profil tersebut, apoteker dapat membuat program yang tepat sehingga dapat meningkatkan kerasionalan pengguna-an obat. Berbagai faktor yang berhubungan dengan kejadian swamedikasi juga menjadi penting. Hal ini selanjutnyan dapat dijadikan dasar untuk membangun strategi pelayanan kesehatan yang optimal.

Meskipun berbagai studi telah meneliti profil pasien yang melakukan swamedikasi dan berbagai faktor yang mendorong swamedikasi, belum terdapat penelitian mengenai profil pasien swamedikasi di Bali, khususnya di daerah Kota Denpasar dan Badung.

\section{METODE PENELITIAN}

Penelitian ini menggunakan metode observasional, yaitu studi cross sectional. Data penelitian di ambil selama 3 bulan yang dimulai pada bulan September 2017-November 2017. Populasi target pada penelitian ini adalah seluruh pasien yang menerima pelayanan kefarmasian di Apotek. Populasi terjangkau dalam penelitian ini adalah pasien yang menerima pelayanan kefarmasian di Apotek yang berada di wilayah Denpasar dan Badung. Populasi diambil dari masing-masing 3 Apotek di Denpasar dan 3 Apotek di Badung.

Teknik pengambilan sampel yang digunakan adalah non probability sampling yaitu consecutive sampling dimana peneliti akan mengambil semua 
subjek yang sesuai dengan kriteria inklusi dan eksklusi, hingga jumlah subjek minimal terpenuhi. Jumlah populasi tidak diketahui, sehingga jumlah sampel dihitung dengan persamaan berikut

$$
\begin{aligned}
\mathrm{n} & =\frac{z_{1-x / s}^{2} \mathrm{P}(1-\mathrm{P})}{\mathrm{d}^{2}} \\
& =\frac{(1,95)^{2} 0,5(1-0,5)}{0,1^{2}} \\
& =97 \text { sampel }
\end{aligned}
$$

Keterangan

$$
\begin{array}{ll}
\mathrm{n} & =\text { Sampel } \\
\mathrm{P} & =\text { Peluang } \\
\mathrm{d} & =\text { Limit error atau presisi absolut } \\
\mathrm{Z}^{2}{ }_{1-\alpha / 2} & =\text { Derajat kepercayaan }
\end{array}
$$

Jadi sampel minimal yang digunakan sebanyak 97 sampel. Jumlah sampel yang diambil dalam penelitian ini sebanyak 230 sampel.

Alat pengambilan data berupa panduan interview (Lampiran 1). Pengambilan data diperoleh berdasarkan keterangan dari pasien. Untuk tingkat keluhan penyakit, dibagi menjadi 3 kategori, yaitu ringan, sedang, dan berat. Pengkategorian ini didasarkan atas pendapat pasien sendiri.

Dilakukan perhitungan frekuensi data dan proporsi data untuk masing masing variabel karakteristik pasien serta nilai tendensi sentral (mean). Pada uji ini, dianalisis adanya hubungan antara berbagai faktor dengan kejadian swamedikasi. Data dianalisis secara multivariat menggunakan analisis regresi logistik.

\section{HASIL}

\section{Karakteristik Sampel Penelitian}

Karakteristik sampel penelitian ditampilkan pada tabel 1 dan 2 .

Tabel 1 Karakteristik Sampel Penelitian untuk Data Kategorik

\begin{tabular}{ccc}
\hline Variabel & $\begin{array}{c}\text { Jumlah } \\
(\mathbf{n})\end{array}$ & \% \\
\hline Jenis Kelamin & & \\
Laki-laki & 96 & 41,7 \\
Perempuan & 134 & 58,3 \\
Status Kehamilan & & \\
Hamil & 8 & 3,5 \\
Tidak Hamil & 222 & 96,5 \\
Status merokok & & \\
Merokok & 43 & 18,7 \\
\hline
\end{tabular}

\begin{tabular}{lcc}
\hline Variabel & $\begin{array}{c}\text { Jumlah } \\
\text { (n) }\end{array}$ & \% \\
\hline Tidak Merokok & 187 & 81,3 \\
Status Pernikahan & & \\
Lajang & 63 & 27,4 \\
Menikah & 165 & 71,7 \\
Janda/Duda & 2 & 0,9 \\
Tingkat pendidikan pasien & & \\
Tidak bersekolah & 11 & 4,8 \\
SD & 15 & 6,5 \\
SMP & 16 & 7,0 \\
SMA & 139 & 60,4 \\
S1 & 46 & 20,0 \\
S2 & 2 & 0,9 \\
S3 & 0 & 0,0 \\
Diploma & 1 & 0,4 \\
Latar belakang pendidikan & & \\
pasien & & \\
Kesehatan & 15 & 6,5 \\
Non Kesehatan & 215 & 93,5 \\
Konsumsi alkohol & & \\
Ya & 13 & 5,7 \\
Tidak & 217 & 94,3 \\
Penyakit Kronis & & \\
Ada & 31 & 13,5 \\
Tidak & 199 & 86,5 \\
Tingkat Keluhan & & \\
Ringan & 111 & 48,3 \\
Sedang & 108 & 47,0 \\
Berat & 11 & 4,8 \\
Layanan Kefarmasian yang & & \\
digunakan & & \\
Resep & 91 & 39,6 \\
Swamedikasi & 139 & 60,4 \\
\hline Total & 230 & $100 \%$ \\
\hline
\end{tabular}

Tabel 2 Karakteristik Sampel Penelitian untuk Data Numerik

\begin{tabular}{lc}
\hline \multicolumn{1}{c}{ Variabel } & $\begin{array}{c}\text { Nilai Rata-rata } \\
\text { (SD) }\end{array}$ \\
\hline Umur (tahun) & $36,89(18,57)$ \\
\hline
\end{tabular}

Tabel 1 menunjukkan bahwa proporsi pasien perempuan lebih besar dibandingkan laki-laki, sebagian besar pasien tidak sedang hamil, dan sebagian besar pasien tidak merokok. Subjek penelitian didominasi oleh pasien yang sudah menikah, tingkat pendidikan SMA, latar belakang pendidikan non-kesehatan, pasien yang tidak mengkonsumsi alkohol, dan tanpa penyakit kronis. Jumlah pasien yang mengalami keluhan dengan derajat ringan dan berat memiliki proporsi yang mirip, sedangkan pasien yang mengalami keluhan berat proporsinya sangat kecil. Rata-rata umur pasien adalah $36,89 \pm 18,57$ tahun 
Karakteristik Pasien yang Menggunakan Layanan Swamedikasi

Karakteristik sampel penelitian yang mendapatkan layanan swamedikasi ditampilkan pada tabel 3 dan 4 .

Tabel 3. Karakteristik Sampel Penelitian yang Memperoleh Layanan Swamedikasi untuk Data Kategorik

\begin{tabular}{|c|c|c|}
\hline Variabel & $\begin{array}{c}\text { Jumlah } \\
(\mathrm{n})\end{array}$ & $\%$ \\
\hline \multicolumn{3}{|l|}{ Jenis Kelamin } \\
\hline Laki-laki & 58 & 41,7 \\
\hline Perempuan & 81 & 58,3 \\
\hline \multicolumn{3}{|l|}{ Status Kehamilan } \\
\hline Hamil & 4 & 2,9 \\
\hline Tidak Hamil & 135 & 97,1 \\
\hline \multicolumn{3}{|l|}{ Status merokok } \\
\hline Merokok & 32 & 23,0 \\
\hline Tidak Merokok & 107 & 77,0 \\
\hline \multicolumn{3}{|l|}{ Status Pernikahan } \\
\hline Lajang & 35 & 25,2 \\
\hline Menikah & 102 & 73,4 \\
\hline Janda/Duda & 2 & 1,4 \\
\hline \multicolumn{3}{|l|}{ Tingkat pendidikan pasien } \\
\hline Tidak bersekolah & 4 & 2,9 \\
\hline SD & 3 & 2,2 \\
\hline SMP & 8 & 5,8 \\
\hline SMA & 92 & 66,2 \\
\hline $\mathrm{S} 1$ & 30 & 21,6 \\
\hline $\mathrm{S} 2$ & 2 & 1,4 \\
\hline S3 & 0 & 0,0 \\
\hline Diploma & 0 & 0,0 \\
\hline \multicolumn{3}{|l|}{$\begin{array}{l}\text { Latar belakang pendidikan } \\
\text { pasien }\end{array}$} \\
\hline Kesehatan & 14 & 10,1 \\
\hline Non Kesehatan & 125 & 89,9 \\
\hline \multicolumn{3}{|l|}{ Konsumsi alkohol } \\
\hline Ya & 9 & 6,5 \\
\hline Tidak & 130 & 93,5 \\
\hline \multicolumn{3}{|l|}{ Penyakit Kronis } \\
\hline Ada & 12 & 8,6 \\
\hline Tidak & 127 & 91,4 \\
\hline \multicolumn{3}{|l|}{ Tingkat Keluhan } \\
\hline Ringan & 88 & 63,3 \\
\hline Sedang & 49 & 35,3 \\
\hline Berat & 2 & 1,4 \\
\hline Total & 139 & $100 \%$ \\
\hline
\end{tabular}

Tabel 4 Karakteristik Sampel Penelitian yang Memperoleh Layanan Swamedikasi untuk Data Numerik

\begin{tabular}{lr}
\hline Variabel & Nilai Rata-rata (SD) \\
\hline Umur (tahun) & $35,06(15,35)$ \\
\hline
\end{tabular}

Tabel 4 menunjukkan bahwa proporsi pasien perempuan yang mendapatkan layanan swamedikasi lebih besar dibanding-kan laki-laki. Subjek penelitian yang mendapatkan layanan swamedikasi didominasi oleh pasien yang tidak hamil, tidak merokok, pasien yang menikah, tingkat pendidikan SMA, latar belakang pendidikan non-kesehatan, tanpa penyakit kronis, dan tidak mengkonsumsi alkohol. Sebanyak lebih dari $65 \%$ pasien yang mendapatkan layanan swamedikasi memiliki tingkat keluhan penyakit yang ringan. Rata-rata umur pasien yang mendapatkan layanan swamedikasi adalah 35,06 \pm 15,35 tahun.

Faktor-Faktor yang Berhubungan dengan Kejadian Swamedikasi di Apotek

Dari hasil analisis didapatkan 6 faktor prediktor yang berpengaruh terhadap kejadian swamedikasi di apotek, yaitu status merokok, tingkat pendidikan pasien, latar belakang pendidikan pasien, jarak tempat tinggal dengan layanan kesehatan, tingkat keluhan penyakit, dan harga obat $(\mathrm{p}<0,05)$.

Tabel 5. Rangkuman Hasil Uji Analisis Regresi Logistik pada Faktor-Faktor Prediktor Kejadian Swamedikasi di Apotek

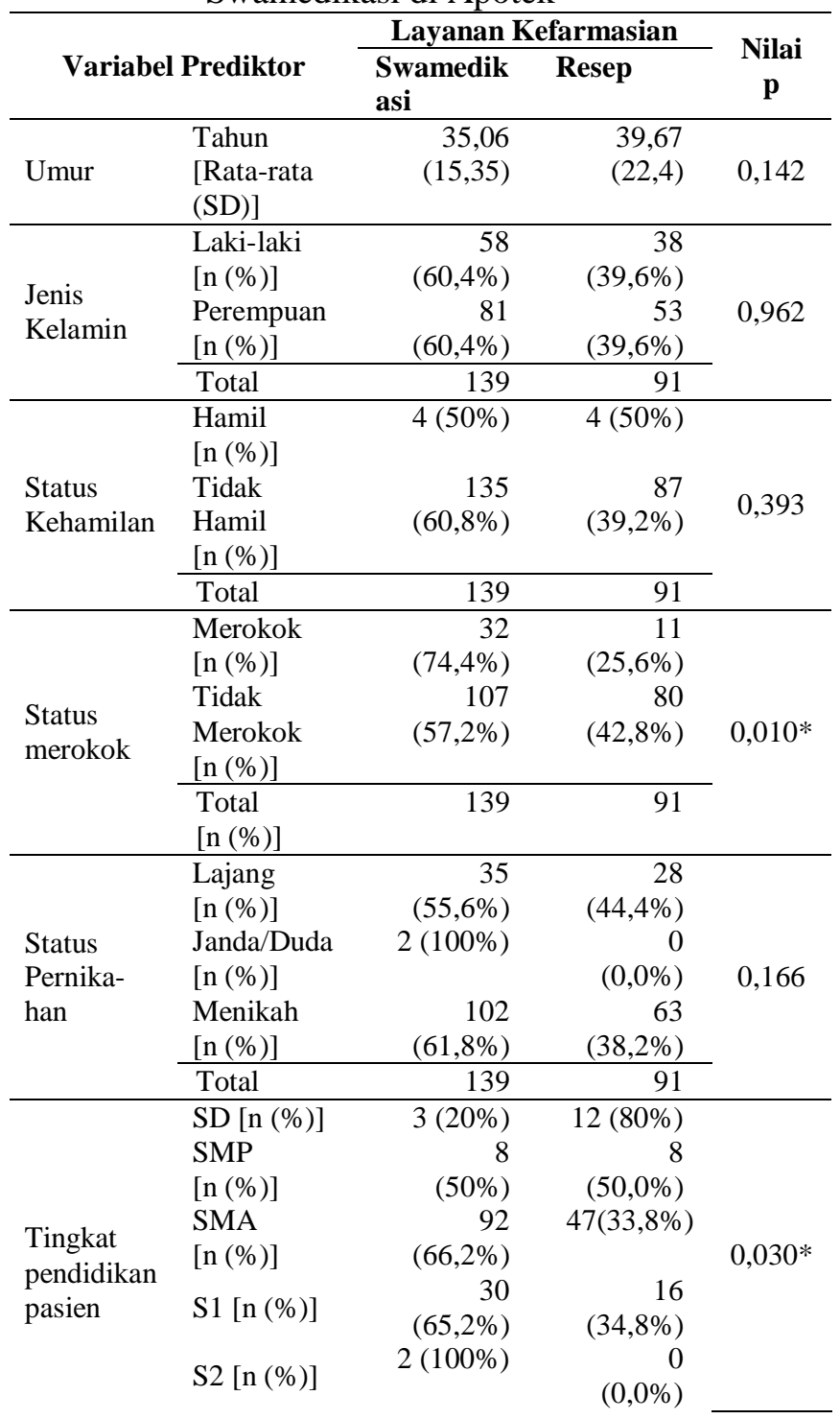




\begin{tabular}{|c|c|c|c|c|}
\hline \multirow{5}{*}{ Variabel } & \multirow[b]{2}{*}{ Prediktor } & \multicolumn{2}{|c|}{ Layanan Kefarmasian } & \multirow{4}{*}{$\begin{array}{c}\text { Nilai } \\
\mathbf{p}\end{array}$} \\
\hline & & \multirow{2}{*}{$\begin{array}{l}\begin{array}{l}\text { Swamedik } \\
\text { asi }\end{array} \\
0(0,0 \%)\end{array}$} & Resep & \\
\hline & $\begin{array}{l}\text { Diploma } \\
{[\mathrm{n}(\%)]}\end{array}$ & & $\begin{array}{r}1 \\
(100 \%)\end{array}$ & \\
\hline & $\begin{array}{l}\text { Tidak } \\
\text { bersekolah } \\
{[\mathrm{n}(\%)]}\end{array}$ & $4(36,4 \%)$ & $\begin{array}{r}7 \\
(63,6 \%)\end{array}$ & \\
\hline & Total & 139 & 91 & \multirow{6}{*}{$0,016^{*}$} \\
\hline \multirow{5}{*}{$\begin{array}{l}\text { Latar } \\
\text { belakang } \\
\text { pendidikan } \\
\text { pasien }\end{array}$} & Kesehatan & 14 & $1(6,7 \%)$ & \\
\hline & {$[\mathrm{n}(\%)]$} & $(93,3 \%)$ & & \\
\hline & Non & 125 & 90 & \\
\hline & $\begin{array}{l}\text { Kesehatan } \\
{[\mathrm{n}(\%)]}\end{array}$ & $(58,1 \%)$ & $(41,9 \%)$ & \\
\hline & Total & 139 & 91 & \\
\hline \multirow{9}{*}{$\begin{array}{l}\text { Tingkat } \\
\text { pendidikan } \\
\text { orang tua } \\
\text { pasien }\end{array}$} & $\mathrm{SD}[\mathrm{n}(\%)]$ & $\begin{array}{r}26 \\
(63,4 \%)\end{array}$ & $\begin{array}{r}15 \\
(36,6 \%)\end{array}$ & \multirow{9}{*}{0,250} \\
\hline & SMP $[\mathrm{n}$ & 19 & 21 & \\
\hline & $(\%)]$ & $(47,5 \%)$ & $(52,5 \%)$ & \\
\hline & SMA [n & 60 & 36 & \\
\hline & $(\%)]$ & $(62,5 \%)$ & $(37,5 \%)$ & \\
\hline & $\mathrm{S} 1[\mathrm{n}(\%)]$ & $\begin{array}{r}20 \\
(76,9 \%)\end{array}$ & $\begin{array}{r}6 \\
(23,1 \%)\end{array}$ & \\
\hline & $\begin{array}{l}\text { Diploma } \\
\text { [n (\%)] }\end{array}$ & $0(0,0 \%)$ & $\begin{array}{r}1 \\
(100 \%)\end{array}$ & \\
\hline & $\begin{array}{l}\text { Tidak } \\
\text { bersekolah } \\
\text { [n (\%)] }\end{array}$ & $\begin{array}{r}14 \\
(53,8 \%)\end{array}$ & $\begin{array}{r}12 \\
(46,2 \%)\end{array}$ & \\
\hline & Total & 139 & 91 & \\
\hline \multirow{3}{*}{$\begin{array}{l}\text { Konsumsi } \\
\text { alkohol }\end{array}$} & $\mathrm{Ya}[\mathrm{n}(\%)]$ & $9(69,2 \%)$ & $\begin{array}{r}4 \\
(30.8 \%)\end{array}$ & \multirow{3}{*}{0,815} \\
\hline & $\begin{array}{l}\text { Tidak } \\
{[\mathrm{n}(\%)]}\end{array}$ & $\begin{array}{r}130 \\
(59,9 \%) \\
\end{array}$ & $\begin{array}{r}(30,8 \%) \\
87 \\
(40,1 \%) \\
\end{array}$ & \\
\hline & Total & 139 & 91 & \\
\hline $\begin{array}{l}\text { Waktu } \\
\text { Kerja }\end{array}$ & $\begin{array}{l}\text { Jam [Rata- } \\
\text { rata (SD)] }\end{array}$ & $\begin{array}{r}31,72 \\
(22,04)\end{array}$ & $\begin{array}{r}28,00 \\
(24,10)\end{array}$ & 0,570 \\
\hline $\begin{array}{l}\text { Penghasil } \\
\text { an/tahun } \\
\text { (dalam } \\
\text { juta) }\end{array}$ & $\begin{array}{l}\text { Rupiah } \\
\text { [Rata-rata } \\
\text { (SD)] }\end{array}$ & $\begin{array}{r}22,287 \\
(20,404)\end{array}$ & $\begin{array}{r}20,736 . \\
(23,117)\end{array}$ & 0,838 \\
\hline \multirow{4}{*}{$\begin{array}{l}\text { Penyakit } \\
\text { Kronis }\end{array}$} & $\begin{array}{l}\text { Ada } \\
{[\mathrm{n}(\%)]}\end{array}$ & $\begin{array}{r}12 \\
(38,7 \%)\end{array}$ & $\begin{array}{r}19 \\
(61,3 \%)\end{array}$ & \multirow{4}{*}{0,314} \\
\hline & Tidak & 127 & 72 & \\
\hline & {$[\mathrm{n}(\%)]$} & $(63,8 \%)$ & $(36,2 \%)$ & \\
\hline & Total & 139 & 91 & \\
\hline $\begin{array}{l}\text { Jarak } \\
\text { tempat } \\
\text { tinggal } \\
\end{array}$ & $\begin{array}{l}\text { Km [Rata- } \\
\text { rata (SD)] }\end{array}$ & $\begin{array}{r}3,41 \\
(6,02)\end{array}$ & $\begin{array}{r}6,08 \\
(8,21)\end{array}$ & $0,000 *$ \\
\hline \multirow{5}{*}{$\begin{array}{l}\text { Tingkat } \\
\text { Keluhan }\end{array}$} & $\begin{array}{l}\text { Ringan } \\
{[\mathrm{n}(\%)]}\end{array}$ & $\begin{array}{r}88 \\
(79,3 \%)\end{array}$ & $\begin{array}{r}23 \\
(20,7 \%)\end{array}$ & \multirow{5}{*}{$0,033^{*}$} \\
\hline & Sedang & 49 & 59 & \\
\hline & {$[\mathrm{n}(\%)]$} & $(45,4 \%)$ & $(54,6 \%)$ & \\
\hline & Berat & 2 & $\begin{array}{r}9 \\
(818 \%)\end{array}$ & \\
\hline & $\frac{[\mathrm{n}(\%)]}{\text { Total }}$ & 137 & $\frac{(01,0 \%)}{82}$ & \\
\hline Harga & Rupiah & 62,342 & 125,052 & \\
\hline $\begin{array}{l}\text { Obat } \\
\text { (dalam } \\
\text { ribuan) }\end{array}$ & $\begin{array}{l}\text { [Rata-rata } \\
\text { (SD)] }\end{array}$ & $(116,730)$ & $(129,372)$ & $0,000 *$ \\
\hline
\end{tabular}

\section{PEMBAHASAN}

\section{Karakteristik Pasien yang Menggunakan}

Karakteristik pasien yang mendapatkan layanan swamedikasi hampir mirip dengan karakteristik pasien secara umum dalam penelitian ini. Pasien perempuan memiliki proporsi yang lebih besar dalam menerima pelayanan swamedikasi di apotek dibanding-kan laki-laki. Hal ini dapat disebabkan oleh perempuan yang memiliki kecenderungan lebih besar untuk memperhatikan gejala penyakit yang muncul dibandingkan laki-laki sehingga perempuan cenderung untuk melakukan konsultasi ke tenaga kesehatan dibandingkan pria, dengan nilai RR 0,68 (CI 95\% 0,68 to 0,69) (Wang et al., 2013).

Subjek penelitian juga sebagian besar merupakan non perokok (77, \%). Hal ini dapat disebabkan oleh proporsi penduuduk yang merupakan perokok lebih rendah dibandingkan non perokok. Menurut data riskesdas tahun 2013, sebagian besar penduduk di provinsi Bali yang berusia di atas 15 tahun $(77,6 \%)$ tidak sedang merokok (Kementrian Kesehatan Republik Indonesia, 2013).

Pada penelitian ini sebanyak $73,4 \%$ pasien yang mendapatkan layanan swamedikasi di apotek adalah pasien yang sudah menikah. Hal ini sesuai dengan penelitian yang dilakukan oleh Bourne (2009). Hal ini dapat disebabkan oleh responden yang sudah menikah memiliki kemungkinan 2,2 kali lebih banyak untuk mengalami keluhan kesehatan dibanding yang tidak pernah menikah (Bourne, 2009).

Subjek penelitian sebagian besar merupakan pasien dengan tingkat pendidikan SMA ke bawah. Hanya sekitar $23 \%$ pasien saja yang memiliki tingkat pendidikan di atas SMA. Hal ini dapat diakibatkan oleh kemungkinan pasien dengan tingkat pendidikan SMA atau lebih rendah cenderung melaporkan lebih banyak keadaan kesehatan yang kurang baik pada dirinya (Fiscella, Goodwin and Stange, 2002), sehingga kemunginan meningkatkan kunjungan ke apotek untuk melakukan swamedikasi. Sebanyak lebih dari 89\% pasien yang melakukan swamedikasi memiliki latar belakang pendidikan non kesehatan. Hal ini dapat disebabkan pasien dengan latar belakang pendidikan kesehatan cenderung lebih menjaga kesehatannya sehingga memiliki tingkat kunjungan ke apotek untuk melakukan swamedikasi menjadi lebih rendah.

Lebih dari $90 \%$ pasien yang mendapatkan layanan swamedikasi tidak mengkonsumsi alkohol. Pasien yang mengkonsumsi alkohol 
memiliki kecenderungan lebih rendah untuk menggunakan layanan kesehatan (Zarkin et al., 2004), yang kemungkinan dapat berkontribusti terhadap rendahnya proporsi pasien pengguna alkohol yang melakukan swamedikasi.

Sebanyak $86,5 \%$ pasien yang mengunjungi apotek tidak memiliki penyakit kronis. Apabila dilihat dari data rata-rata usia sampel dalam penelitian ini, yaitu 36,89 tahun, menunjukkan usia yang belum tergolong geriatri, sehingga kemungkinan risiko untuk mengalami penyakit kronis menjadi lebih rendah. Selain itu pelayanan swamedikasi kemungkinan dilakukan untuk penyakit-penyakit non kronis, dan ke-cenderungan pasien yang mengalami penyakit kronis untuk melakukan pemeriksaan ke dokter.

Apabila dilihat dari parameter tingkat keluhan, sampel penelitian sebagian besar memiliki tingkat keluhan penyakit yang ringan dan sedang. Hanya $1,4 \%$ pasien yang memiliki tingkat keluhan berat. Hal ini kemungkinan menunjukkan bahwa pasien dengan tingkat keluhan berat cenderung tidak menjadikan swamedikasi sebagai pilihan pertamanya untuk mendapatkan layanan kesehatan.

\section{Faktor-Faktor yang Berhubungan dengan Kejadian Swamedikasi di Apotek}

Nilai rata-rata umur pasien yang menggunakan layanan resep lebih besar dibandingkan pasien yang menggunakan layanan swamedikasi $(39,67 \pm 22,40$ vs $35,06 \pm 15,35$ tahun). Namun, hasil uji regresi logistik biner pada variabel umur menunjukkan tidak adanya hubungan yang bermakna antara umur dengan kejadian swamedikasi $(\mathrm{p}=0,142)$. Hasil yang tidak signifikan ini didukung oleh beberapa penelitian. Penelitian yang dilakukan oleh Saeed pada 430 pasien di primary care clinic di daerag Riyadh menunjukkan tidak adanya pengaruh usia pada kejadian swamedikasi (Saeed, 1988). Penelitian yang dilakukan oleh Nunez (2017) pada kecenderungan swamedikasi dengan antibiotik pada mahasiswa tingkat perguruan tinggi di daerah Trujillo, Peru menunjukkan tidak adanya hubungan antara umur dan tingkat swamedikasi $(\mathrm{p}=0,46) \quad$ (Núñez, Tresierra-Ayala and GilOlivares, 2016).

Hasil regresi logisitik pada penelitian ini menunjukkan tidak ada hubungan yang bermakna antara parameter gender dan kejadian swamedikasi $(\mathrm{p}=0,962)$. Hal ini didukung oleh beberapa penelitian, misalnya penelitian yang dilakukan oleh Oluyemi. Penelitian ini bertujuan melihat faktor-faktor yang mempengaruhi perilaku swamedikasi pada banker di daerah Ilorin, Nigeria dengan 240 responden. Hasil penelitian menunjukkan tidak ada pengaruh jenis kelamin terhadap perilaku swamedikasi $(\mathrm{p}=0.231)$ (Oluyemi et al., 2015). Penelitian lain menggunakan 240 pasien elderly (> 75 tahun) menunjukkan tidak adanya hubungan yang bermakna antara jenis kelamin dengan perilaku swamedikasi (Vacas Rodilla et al., 2009)

Sebanyak $50 \%$ pasien hamil menggunakan layanan swamedikasi. Hasil regresi logistik menunjukkan tidak adanya hubungan yang signifikan antara status kehamilan dengan kejadian swamedikasi $(\mathrm{p}=0,393)$. Studi yang dilakukan oleh Ebrahimi menjunjukkan adanya penurunan perilaku swamedikasi antara masa sebelum hamil dan selama kehamilan, yaitu dari $63,9 \%$ menjadi $43,5 \%$. Berbagai penelitian menunjukkan perempuan jelas cenderung untuk melakukan swamedikasi dan mereka biasanya swamedikasi dilakukan untuk mengatasi masalah seperti dismenore, hingga meringankan gejala menopause, gangguan haid dan mencegah osteoporosis. Namun, selama kehamilan terjadinya penurunan kejadian swamedikasi dapat diakibatkan oleh ketakutan akan efek samping yang mungkin terjadi pada janin dan malformasi embrio, sehingga perempuan hamil akan lebih berhati-hati terkait dengan pengobatannya (Ebrahimi et al., 2017). Tidak signifikannya hasil analisis dalam penelitian ini dapat diakibatkan oleh kecilnya proporsi pasien hamil yang berhasil terjaring dalam penelitian.

Studi ini menunjukkan adanya hubungan antara status merokok dengan kejadian swamedikasi $(\mathrm{p}=0,010)$. Hasil ini didukung oleh penelitian yang dilakukan oleh Mustafa dan Rohra (2017) pada 1046 pasien tingkat universitas di Saudi Arabia yang menunjukkan status merokok, berkaitan dengan tingkat kejadian swamedikasi $(\mathrm{p}=0,031)$ (Mustafa and Rohra, 2017). Terdapat hubungan positif antara merokok dan penggunaan obat-obatan menunjukkan bahwa tembakau menyebabkan bahaya bagi kesehatan baik kronis maupun akut (Moraes et al., 2011).

Proporsi pasien yang menikah lebih besar memilih swamedikasi dibandingkan pelayanan resep. Hal yang sama juga terjadi pada pasien yang belum menikah maupun yang sudah bercerai. Hasil penelitian menunjukkan tidak adanya hubungan yang bermakna antara status pernikahan dan perilaku swamedikasi $(\mathrm{p}=0,116)$. Hal ini didukung oleh penelitian yang dilakukan oleh Oluyemi et al (2015). Penelitian ini bertujuan melihat faktorfaktor yang mempengaruhi perilaku swamedikasi 
pada banker di daerah Ilorin, Nigeria dengan 240 responden. Hasil penelitian menunjukkan tidak ada pengaruh status pernikahan terhadap perilaku swamedikasi ( $\mathrm{p}=0,361)$ (Oluyemi et al., 2015)

Tingkat pendidikan yang lebih tinggi cenderung untuk memilih layanan swamedikasi dibandingkan layanan resep. Hasil uji regresi logistik biner juga menunjukkan adanya hubungan yang bermakna antara tingkat pendidikan dan kejadian swamedikasi $(\mathrm{p}=0,030)$. Sebagaimana yang ditunjukkan oleh World Health Organization (WHO), swamedikasi yang bertanggung jawab adalah praktik yang muncul dari konsep modern dalam perawatan diri, dimana populasi yang lebih banyak memperoleh informasi dan up-to-date akan memiliki usaha yang lebih besar dalam menjaga kesehatannya (Pan et al., 2012). Berbagai penelitian mendukung hasil ini. Level pendidikan lebih tinggi cenderung memilih untuk menggunakan layanan swamedikasi $(\mathrm{OR}=2,5$; 95\% CI:1,016-6,230; p=0,046) (Afolabi, 2008; Machado-Alba et al., 2014; Papakosta, Zavras and Niakas, 2014) Individu dengan pendidikan tinggi memiliki lebih banyak memiliki pengetahuan tentang obat-obatan dibandingkan dengan yang tingkat pendidikannya lebih rendah, dan mungkin saja lebih berkompeten dalam melakukan swamedikasi (Papakosta, Zavras and Niakas, 2014).

Menurut Figueiras, semakin terdidik seseorang, maka orang tersebut akan memiliki kepercayaan diri lebih dalam mendiagnosis diri dan melakukan pengobatan sendiri dan kurang kepercayaan di dokter, terutama dengan adanya kelainan akut,dan mereka lebih mampu memilih yang obat yang sesuai untuk memperhatikan gejala mereka. Sedangkan orang yang kurang berpendidikan lebih memilih konsultasi medis untuk menangani keluhannya karena kurangnya pengetahuan tentang obat-obatan (Figueiras, Caamaño and Gestal-Otero, 2000).

Latar belakang pendidikan kesehatan cenderung lebih memilih swamedikasi dibandingkan dengan pasien dengan latar belakang pendidikan non kesehatan $(\mathrm{p}=0,016)$. Hal ini sesuai dengan penelitian yang dilakukan oleh Helal dan Albou-Elwafa yang menunjukkan bahwa mahasiswa dengan latar belakang pendidikan kesehatan memiliki kecenderungan swamedikasi yang lebih tinggi dibandingkan mahaswa non kesehatan (OR 2,2 dengan CI 95\% 1,6-2,9). Hal ini ini dapat pula dikaitkan dengan tingkat pengetahuan mengenai obat-obatan yang lebih banyak pada pasien dari latar belakang pendidikan non-kesehatan, terkait dengan informasi mengenai obat-obatan yang mungkin diperoleh di bangku pendidikan (Helal and Abou-Elwafa, 2017).

Pada studi ini, pasien dengan tingkat pendidikan orang tua yang lebih rendah cenderung menggunakan layanan resep dibandingkan layanan swamedikasi. Namun dalam penelitian ini, perbedaan tingkat pendidikan orang tua tidak berpengaruh signifikan terhadap layanan kefarmasian yang dipilih $(0,250)$. Hal ini kemungkinan dapat disebabkan oleh karakteristik umur pasien yang rata-rata dewasa sehingga pasien memiliki preferensi sendiri dalam memilih layanan kesehatan swamedikasi atau resep. Hasil yang cenderung signifikan terjadi pada kelompok pasien usia pelajar, seperti yang ditunjukkan pada penelitian yang dilakukan Lukovic et al (2014) pada medical student yang menemukan bahwa student yang orang tuanya hanya memiliki tingkat pendidikan lebih tinggi memiliki kecenderungan 1,5 kali lipat lebih tinggi untuk melakukan swamedikasi (Lukovic et al., 2014).

Adanya penyakit kronis tidak berkaitan dengan pilihan layanan swamedikasi atau resep pada pasien yang pergi ke apotek $(\mathrm{p}=0,314)$. Hasil ini berbeda dengan beberapa hasil penelitian. Papakosta et al menyatakan, absennya penyakit kronis merupakan faktor risiko seseorang melakukan swamedikasi (OR: 0.30, 95\% CI: 0.098-0.92 (Papakosta, Zavras and Niakas, 2014). Hal ini dapat disebabkan oleh beberapa alasan. Individu dengan penyakit kronis cenderung tidak melakukan swamedikasi karena adanya hubungan jangka panjang antara dokter dan pasien dengan penyakit kronis, dan mereka dapat mengunjungi dokter pribadi mereka lebih sering karena penyakit mereka atau gejala lainnya (Berzanskyte et al., 2006). Kedekatan hubungan antara dokter dengan pasien ini juga menjadi alasan pasien lebih memilih menggunakan pelayanan resep (Farmer et al., 2006). Perbedaan hasil penelitian ini dengan literatur ini dapat disebabkan oleh regulasi di Indonesia yang cukup longgar dan membiarkan obat-obatan keras dapat dibeli secara bebas, sehingga Pasien-pasien dengan penyakit kronis dapat membeli obat kronik mereka tanpa resep.

Penelitian ini menunjukkan adanya hubungan yang bermakna antara jarak layanan kesehatan dengan tingkat swamedikasi $(\mathrm{p}=0,000)$. Jarak ratarata tempat tinggal dengan layanan kesehatan pada pasien dengan swamedikasi lebih dekat dibandingkan pasien dengan layanan resep $(3,41 \pm$ $6,02$ vs $6,08 \pm 8,21)$. Hal ini didukung oleh penelitian yang dilakukan oleh Ocan et al (2014). Studi pada pasien di Uganda ini menunjukkan jarak dengan fasilitas kesehatan yang lebih jauh merupakan faktor yang berkaitan dengan 
swamedikasi penggunaan agen antimicrobial (Ocan et al., 2014). Perbedaan hasil ini kemungkinan dapat disebabkan oleh faktor kepercayaan pasien terhadap dokter tertentu. Meskipun jarak tempuh dengan dokter (fasilitas layanan kesehatan) cukup jauh, pasien cenderung tetap menempuh jarak tersebut dikarenakan tingginya kepercayaan pasien pada sosok dokter yang telah merawatnya.

Pasien dengan tingkat keluhan yang lebih ringan cenderung memilih layanan swamedikasi dibandingkan resep $(\mathrm{p}=0,033)$. Hal ini sesuai dengan penelitian yang dilakukan oleh Jallilian et al (2013) pada pengunjung apotek di daerah Hamadhan, Iran, yang menyatakan bahwa tingkat keparahan penyakit merupakan faktor yang berkaitan dengan swamedikasi (Jalilian et al., 2013). Hal senada diungkapkan oleh Arute et al, yang juga memperlihatkan hubungan signifikan antara tingkat keparahan penyakit dan perilaku swamedikasi ( $\mathrm{p}<0,001)$ (Arute et al., 2013). Hal ini dapat disebabkan oleh penilaian pasien mengenai kesembuhannya. Pasien cenderung menilai bahwa keluhan yang ringan dapat diatasi sendiri melalui swamedikasi tanpa konsultasi lebih lanjut dengan dokter.

Harga obat yang lebih murah menjadi faktor risiko seseorang lebih cenderung memilih swamedikasi dibandingkan dengan layanan resep $(\mathrm{p}=0,000)$. Swamedikasi yang bertanggung jawab terbukti dapat menurunkan cost (biaya) pengobatan yang mungkin menjadi alasan bagi pasien untuk memilih swamedikasi (Bennadi, 2014). Beberapa parameter memiliki distribusi kelompok pasien yang sangat berbeda, misalnya pada kelompok pasien berdasarkan status kehamilan hanya menyertakan $3,5 \%$ pasien yang hamil; Tingkat keluhan hanya menyertakan 4,8\% dengan tingkat keluhan berat; Parameter konsumsi alkohol hanya menyertakan $5,7 \%$ pasien yang mengkonsumsi alkohol. Hal tersebut kemungkinan dapat menyebabkan tidak signifikannya pengaruh beberapa parameter terhadap kejadian swamedikasi.

\section{SIMPULAN}

Berapa prevalensi layanan swamedikasi di Apotek wilayah Kota Denpasar dan Badung adalah sebesar $60,4 \%$. Faktor-faktor yang berhubungan dengan kejadian swamedikasi di Apotek wilayah Denpasar dan Badung adalah status merokok, tingkat pendidikan pasien, latar belakang pendidikan pasien, jarak tempat tinggal, tingkat keluhan, dan harga oba, sedangkan faktor umur, jenis kelamin, status kehamilan, status pernikahan, tingkat pendidikan orang tua, konsumsi alcohol, waktu kerja, penghasilan, serta adanya penyakit kronis tidak berkaitan dengan pilihan pasien untuk memilih swamedikasi.

\section{UCAPAN TERIMA KASIH}

Ucapan terima kasih diberikan semua pihak yang membantu dalam penyelesaian jurnal ini terutama kepada seluruh pasien yang terlibat dalam penelitian ini, apotek yang membantu dalam pengambilan data, serta IIK Medika Persada Bali.

\section{DAFTAR PUSTAKA}

Abay, S. and Amelo, W. (2010) Assessment of self-medication practices among medical, pharmacy, and health science students in Gondar University, Ethiopia.J Young Pharm.2(3).pp. 306-310.

AESGP (2004) The economic and public health value of self-medication.

Afolabi, A. O. (2008) Factors Influencing the Pattern of Self-Medication in an Adult Nigerian Population.Annals of African Medicine.7(3).pp. 120-127. doi: 10.4103/1596-3519.55666.

Arute, J. E., Ud, A., Akonoghrere R and So, A. (2013) Self-Medication Practices Among Adults in Delta State, Nigeria.AJPRD.5(1).pp. $11-16$.

Bennadi, D. (2014) Self-medication: A current challenge.Journal of Basic and Clinical Pharmacy.5(1).p. 19. doi: 10.4103/09760105.128253.

Berzanskyte, A., Valinteliene, R., HaaijerRuskamp, F., Gurevicius, R. and Grigoryan, L. (2006) Self-medication with antibiotics in Lithuania.International Journal of Occupational Medicine and Environmental Health.19(4).pp. 246-253.

Bourne, P. A. (2009) Self-rated health and health conditions of married and unmarried men in Jamaica.N Am J Med Sci.1(7).pp. 345-352.

Choonar, I. and Gill, A. (1996) Nunn A. Drug to deficit servillance in children. $B r \quad j \quad d i n$ pharmacology.42.pp. 407-410. 
Clavinjo, H. (1995) Self-medication during pregnancy.World Health Forum.16.pp. 403404.

Ebrahimi, H., Atashsokhan, G., Amanpour, F. and Hamidzadeh, A. (2017) Self-medication and its risk factors among women before and during pregnancy.PAMJ.27(183).pp. 1-8. doi: 10.11604/pamj.2017.27.183.10030.

Farmer, J., Iversen, L., Campbell, N., Guest, C., Chesson, R., Deans, G. and MacDonald, J. (2006) Rural/urban differences in accounts of patients' initial decisions to consult primary care.Health \& Place.12(2).pp. 210-221.

Figueiras, A., Caamaño, F. and Gestal-Otero, J. (2000) Sociodemographic factors related to self-medication in Spain.European Journal of Epidemiology.16(1).pp. 19-26.

Figueroas, A., Cacmaso, F. and Guestal, O. (2011) Socio demographic factors related to selfmedication in Spain.Eru J Epidemical.11(1).pp. 19-26.

Fiscella, K., Goodwin, M. A. and Stange, K. C. (2002) Does patient educational level affect office visits to family physicians? Journal of the National Medical Association.94(3).pp. 15765 .

Galato, D., Galafassi, L. D. M., Alano, G. M. and Trauthman, S. C. (2009) Responsible selfmedication: Review of the process of pharmaceutical attendance.Brazilian Journal of Pharmaceutical Sciences.45(4).pp. 625-633. doi: 10.1590/S1984-82502009000400004.

Helal, R. M. and Abou-Elwafa, H. S. (2017) Selfmedication in university students from the city of mansoura, Egypt.Journal of Environmental and Public Health.2017.

Hughes, C., McElnay, J. and Fleming, G. (2001) Benefits and risks of self medication.Drug Saf.24.pp. 1027-1037.

Jalilian, F., Seyyed Mohammad Mehdi Hazavehei, Vahidinia, A. A., Jalilian, M. and Moghimbeigi, A. (2013) Prevalence and Related Factors for Choosing Self-Medication among Pharmacies Visitors Based on Health Belief Model in Hamadan Province, West of Iran.JRHS.13(1).pp. 81-85.
James, H., Handu, S., Khalid, A., Khaja, A., Otoom, S. and Sequeira, R. (2006) Evaluation of Knowledge, Attitude and Practise of Selfmedication among first year medical student.Med Princ Pract.15.pp. 270-275.

Kasilo, O., Nacho, C. and Mutangadura, E. (1991) Epidemiology of household medications in urban Gweru Harare.Cent Afr med.37.pp. 167171.

Kementrian Kesehatan Republik Indonesia (2013) Riset Kesehatan Dasar (Riskesdas). Jakarta: Badan Penelitian dan Pengembangan Kesehatan.

Loyola Filho, A., Uchoa, E., Guerra, H., Firmo, J. and Lima Costa, M. (2002) Prevalência e fatores associados à automedicação: resultados do projeto Bambuí.Rev. Saúde Pública.36(1).pp. 55-62.

Lukovic, J. A., Miletic, V., Pekmezovic, T., Trajkovic, G., Ratkovic, N., Aleksic, D. and Grgurevic, A. (2014) Self-medication practices and risk factors for self-medication among medical students in Belgrade, Serbia.PLoS ONE.9(12).pp. 1-14. doi: 10.1371/journal.pone.0114644.

Machado-Alba, J. E., Echeverri-Cataño, L., Londoño-Builes, M. J., Moreno-Gutiérrez, P. A., Machado-Alba, J. E., Echeverri-Cataño, L. F., Ochoa-Orozco, S. A. and Ruiz-Villa, J. O. (2014) Social, cultural and economic factors associated with self-medication.Biomédica ARTÍCULO ORIGINAL Biomédica.3434.pp. 580-8580. doi: 10.7705/biomedica.v34i4.2229.

Martins, A., Miranda, A., Mendes, Z., Soares, M., Ferreira, P. and Nogueira, A. (2002) Selfmedication in a Portuguese urban population: a prevalence study.Pharmacoepidemiol Drug Safety.11.pp. 409-414.

Moraes, A. C. F. de, Delaporte, T. R. M., MolenaFernandes, C. A. and Falcão, M. C. (2011) Factors associated with medicine use and self medication are different in adolescents.Clinics.66(7).pp. 1149-1155.

Murray, M. and Callaran, C. (2003) mproving medication use for older adults: An integrated research agenda.Ann Intern Med.139.pp. 24242429. 
Mustafa, O. M. and Rohra, D. K. (2017) Patterns and determinants of self-medication among university students in Saudi Arabia.Journal of Pharmaceutical Health Services Research.8(3).pp. 177-185.

Núñez, M., Tresierra-Ayala, M. and Gil-Olivares, F. (2016) Antibiotic self-medication in university students from Trujillo, Peru.Medicina Universitaria.18(73).pp. 205209. doi: 10.1016/j.rmu.2016.10.003.

Ocan, M., Bwanga, F., Bbosa, G., Bagenda, D., Waako, P., Ogwal-Okeng, J. and Obua, C. (2014) Patterns and Predictors of Self Medication in Northern Uganda.Plos One.9(3).p. e92323.

Oluyemi, J. A., Yinusa, M. ., Abdullateef, R., Sunday, A. and Kehinde, K. (2015) Factors Influencing the Practice of Self-Medication among Bankers in Selected New Generation Banks in Ilorin Nigeria.International Journal of Economics \& Management Sciences.4(2).pp. 17. doi: 10.4172/2162-6359.1000.

Pagane, J., Ross, S., Yaw, J. and Polsky, D. (2007) Self medication and health insurance coverage in Mexico.Health Policy.75.pp. 170-177.

Pan, H., Cui, B., Zhang, D., Farrar, J., Law, F. and Ba-Thein, W. (2012) Prior knowledge, older age, and higher allowance are risk factors for self-medication with antibiotics among university students in southern China.PloS one.7.p. e41314.

Papakosta, M., Zavras, D. and Niakas, D. (2014) Investigating factors of self-care orientation and selfmedication use in a Greek rural area.Rural and Remote Health.14(2).pp. 1-14.

Petty, D. (2003) Drugs and professional interactions: the modern day pharmacist.Heart.V(89).pp. 31-32.

Saeed, A. (1988) Self medication among primary care patients in Faradak clinic in Riyadh.Soc Sci Med.27.p. 119.
Sawalha, A. (2008) A descriptive study of selfmedication practices among Palestinian medical and nonmedical university students.Res Soc Adm Pharm.4(2).pp. 164-172.

Shankar, P. and Partha P, S. N. (2002) Self medication and non-doctor prescription practices in pokhara valley, western Nepal; a questionnaire based study.BMC Fam Pract.p. 317.

Shankar, P., Partha, P. and Shenoy, N. (2002) Self medication and nondoctor prescription practices in Pokhara Valley, Western Nepal: a questionnaire-based study.BMC Family Practice.3.p. 17.

Tenaw, A. and Tsige, G. (2004) Assessment of consumer drug knowledge in Addis Ababa: Across-sectional survey.Ethiopian Journal of health scienc.14(2).pp. 71-80.

Vacas Rodilla, E., Castell Dag, I., Sánchez Giralt, M., Pujol Algué, A., Pallarés Comalada, M. C. and Balagué Corbera, M. (2009) Automedicación y ancianos. La realidad de un botiquín casero.Atencion Primaria.41(5).pp. 16. doi: 10.1016/j.aprim.2008.09.018.

Wang, Y., Hunt, K., Nazareth, I., Freemantle, N. and Petersen, I. (2013) Do men consult less than women? An analysis of routinely collected UK general practice data.BMJ Open.3(8).pp. 1-8.

Whittington, Z., Cantrill, J., Hassell, K., Bates, F. and Noyce, P. (2001) Community pharmacy management of minor conditions: the "at the chemist" scheme.Pharm J.266.pp. 425-428.

WHO (2000) WHO guidelines for the regulatory assessment of medicinal products for use in self medication.

Zarkin, G. A., Bray, J. W., Babor, T. F. and Higgins-Biddle, J. C. (2004) Alcohol drinking patterns and health care utilization in a managed care organization.Health Serv.Res.39(3).pp. 553-570. 